Mesned İlahiyat Araştırmaları Dergisi / The Journal of Mesned of Theological Studies ISSN 2667-7075| e-ISSN 2687-3605 | https://dergipark.org.tr/tr/pub/mesned

Cilt (Vol.) 12 Sayı (Issue 2) Güz - (Autumn) 2021

ARAŞTIRMA MAKALESI | RESEARCH ARTICLE

(Bu makalenin intihal içermediği benzerlik tarama programlarıyla teyit edilmiştir. / The similarity that this article does not contain plagiarism, has been confirmed by plagiarism checker programs.)

Doi: $10.51605 /$ mesned.894589

Gönderim Tarihi: 10.03.2021 Kabul Tarihi: 24.12.2021

\title{
Kur’ân’da Ġurūr Kelimesi ve “g̀-r-r” Kökünün Geçtiği Ayetler Üzerine Bir İnceleme
}

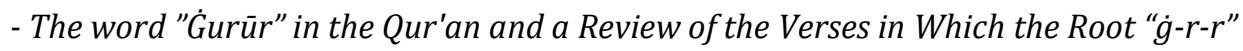
Passes-

\section{Hasan Fehmi Ulus}

Atıf/Citation: Ulus, Hasan Fehmi. “Kur'ân'da Ġurūr Kelimesi ve 'g̀-r-r' Kökünün Geçtiği Ayetler Üzerine Bir İnceleme/ The word 'Gurūr' in the Qur'an and a Review of the Verses in Which the Root 'g-r-r-r' Passes." Mesned Illahiyat Araștırmaları Dergisi / The Journal of Mesned of Theological Studies, (Güz 2021-2): 407-429.

Öz:

Bir hayat ve hidayet kitabı olan Kur'ân, okunmak, anlaşılmak ve içerdiği emir ve hükümlerle amel edilmek için Allah tarafından gönderilmiștir. Kur'ân'ı anlamada ayetleri olușturan kelimelerin anlaşılması öncelikli bir zaruret olarak karşımıza çıkar. Kur'ân'da gurūr kelimesi ve "g̈rr" kökünün diğer türevleri yirmi yedi yerde geçmektedir. "g̈rr" kökünün ve bu kökten türetilmiș kelimelerin Câhiliye dönemi Arap șiirinde de kullanıldığı görülmektedir. Kökün lügatlerde esas itibariyle elbise ve derideki kırılma, kıvrım-büklüm anlamına geldiği belirtilir. Başka bir görüşte gar kelimesinin herhangi bir tesirle bir șeyde meydana gelen ve cehalet, aldanma, eksilme, kırılma gibi sonuçlara götüren gaflet anlamına geldiği ifade edilir. Kökten türetilen kelimelerin tamamının bu temel anlam eksenine bağlı olarak farklı manalarda kullanıldığı görülmektedir. Nitekim bu kökten gelen gurūr kelimesinin bâtıl, boş şeyler anlamına geldiği ifade edilir.

"g̈rr" kökünün ve bu kökten gelen kelimelerin Câhiliye dönemi Arap şiirinde de aynı manalarda kullanıldığı, Kur'ân'ın inișinden sonra herhangi bir değișikliğin olmadığı tespit edilmiștir. Ancak, Kur'ân'ın inişiyle birlikte bu kökten gelen kelimelerin anlamlarında genişleme olduğu söylenebilir. Bunun bașlıca sebebi, Kur'ân'la birlikte değișen ve derinlik kazanan dünya ve hayat algısı ve bunlar temellendiren ayetlerde bu kelimelerin ön planda kullanılması olmalıdır. Hadislerde de bu kökten gelen kelimeler aynı manalarda kullanılmıştır. Nitekim çalışmamızda buna dair örnekler verilmiștir

Kur'ân terminolojisi kaynaklarında gurūr kelimesinin birbirine yakın manalarda açılandığını görmekteyiz. Bu manaları insanın mal, makam, dünyanın câzibesi, şeytan iğvâsı, nefis ve benzeri şeyler tarafından aldatılması șeklinde özetlenebileceğini söylemek mümkündür. Lügat ve terminoloji kay-

Dr. Öğretim Üyesi, Kırklareli Üniversitesi İlahiyat Fakültesi, hasanfehmiulus@klu.edu.tr Orcid: 0000-0002-9329-2393 
naklarında "ġrr" kökünün manası izah edilirken çoğunlukla kökün müteradifi olan ve aldatmak anlamındaki "h-d-'a” kelimesi kullanılmaktadır. Açıklamalarda öne çıkan ortak anlamın, kişinin bazı zaafları yüzünden normal halin dışına çıkması sonucu aldanma ve aldatılmaya maruz kalması olduğu anlaşılmaktadır. Bunun da kelimenin kökündeki kırılma, kıvrım-büklüm anlamıyla uyumlu düştüğü görülmektedir.

Kur'ân'ın farklı ayetlerde geçen kök ve türevlerinin genel ifadesiyle aldatma, aldanma anlamında kullanıldığı ancak, ayetlerin kendi bütünlüğü, bağlamı ve nüzul sebebine bağlı olarak aldatma ve aldanmanın sebep ve sonuçları itibariyle anlam nüansları içerdiği görülmüştür. Ayetlere bakıldığında aldanma sebeplerinin bașında, dünya hayatının cazibesi, mal-mülk, mevki, boș hayâller-hevesler şeytan iğvâsı gibi etkenlerin geldiği, güdülen gaye ve hedefin de insana Allah'ı ve âhireti unutturmak olduğu anlaşılmaktadır.

"ġ̀r" kökünden gelen kelimelerin, gurūr kelimesi dâhil daha ziyade dünya hayatıyla ilgili ayetlerde geçtiğini görmekteyiz. Bu ayetleri yer aldıkları nüzul tertibine göre belli başlıklar altında incelemeye çalıșırken, önceliği gurūr kelimesinin geçtiği ayetlere verdik. Dünya hayatından, șeytandan; kâfir, münâfık ve zâlimlerden bahseden ayetlerin bütününe ve müfessirlerin görüşlerine bakıldığında ayetlerdeki ġurūr kelimesinin aldatma, aldanma manasında kullanıldı̆̆ı görülmektedir. Ayetlerin tefsiriyle ilgili müfessir görüşleri de bu ortak manada toplanmaktadır. Genel ifadesiyle insanın hayat algısı ve ona bağlı hal ve harekâtındaki kırılmayı işaret eden bu mananın kelimenin kök anlamına da uygun düştügü anlaşılmaktadır.

Ayrı bir başlık altında incelediğimiz kelimelerden biri de ġarūr kelimesidir. Ġarūr kelimesi çok aldatan manasına gelmektedir. Kelime, tașıdığı bu mana itibariyle müfessirlerce dünya ve șeytan olarak da yorumlanmaktadır. . Garūr kelimesinin ayetlerde Allah ile çok aldatan şeklinde ifade edildiğini görüyoruz. Özellikle şeytanın müşriklere "Sizler seçkin insanlarsınız, Allah sizleri hesaba çekmez.", mü'minlere de "Allah'ın rahmeti boldur, sizlere azap etmez." şeklinde telkinlerde bulunarak insanları aldattıkları ifade edilir.

“ğrr” kökünden gelen diğer kelimelerin geçtiği ayetleri “Dünya hayatıyla ilgili ayetler” ve “Genel konularla ilgili ayetler" şeklinde iki ayrı başlık altında incelemeye çalıştık. Toplam altı ayetten oluşan dünya hayatıyla ilgili ayetlerde aldatma manalarında kullanıldığı görülmektedir. Bu ayetlerde insanların, dünya hayatının câzibesine kapılıp âhireti unutmaması, aldanmaması uyarısında bulunulmaktadır.

Genel konular başlığı altında toplanan altı ayette ise insanın Allah hakkında türlü sebeplerle yanılmasından, Allah'ın ayetleriyle mücadeleye girișenlerin gösterişli hayatlarına aldanılmaması gerektiği, boș hayallere kapılmamak ve yanıltıcı söz ve hallere itibar edilmemesi gerektiğinden bahsedilmektedir. Ayetlerde kötü sonuçlara götüren eylemlerden bahsedilirken bu kökten gelen kelimeler kullanılmıştır. Çalışmada ayrıca, gurūr kelimesinin bir anlam kaymasına uğrayarak Türkçede övünme, şeref, onur ve büyüklenme manalarında kullanıldığından bahsedilmiştir.

Anahtar Kelimeler: Tefsir, Gurur, Kur'ân, Hadis, Kültür, Toplum.

\section{Summary:}

Thev Qur'an, a book of life andguidance, has been sent by Allah to be recited, understood, and done with the commandments and provisions it contains. In understanding theQur'an, understandingthewordsthatmakeuptheverses is a priority. In the Qur'an, which is nazil in the Arabic language, "the word gurūr" and other derivatives of the root "g-r-r" are mentioned in twenty-seven places. It is seen that the root "grr" and the words derived from this root were also used in Arabic poetry of the age of ignorance.

In dictionaries, it is noted that the root "g-r-r" means curl-twist, mainly in dress and skin. In another opinion, the word "gar" means heedlessness, which occurs in something with any effect and leads to consequences such as ignorance, deception, diminishment, breakage. all of the words derived from the "Ġar "root are used in different meanings depending on this basic axis of meaning. As a matter of fact, it is stated that the word gurūr, which comes from this root, means superstitious, empty things. 
$\dot{\mathrm{G}}-\mathrm{r}-\mathrm{r}$ and the words from this root were used in the same meanings in Arabic poetry of the ignorant period, and that there were no changes after the descent of the Qur'an. However, with the descent of the Qur'an, it can be said that there is an expansion in the meaning of words that come from the root. The main reason for this should be the perception of the world and life, which changes and gains depth with the Qur'an, and the use of these words at the forefront in the versions that base them. In the hadith, the words from this root are used in the same meanings, and examples of this are given in the study.

In the sources of Qur'anic terminology, we see that the word "gurūr" is explained in close meanings. These meanings are Wealth, Authority, power, the charm of the world, the devil, desires, etc. it is possible to sum it up in the form of deceiving people in ways. Word and terminology sources explain the meaning of the root g-r-r, mostly the word h-d-'a, which is the muteradif of the root and means to deceive, is used. It is understood that the common meaning contained in the explanations is that the person is subjected to deception and deception as a result of being left out of the normal situation due to some of his weaknesses. This, in turn, seems to be consistent with the meaning of the breaking bend at the root of the word. The roots and derivatives of "g-r-r" in different surahs of the Qur'an are generally used in the sense of deception and deception, but the verses contain nuances of meaning in terms of the causes and consequences of deception and deception, depending on the integrity, context and cause of nuzul.Looking at the verses, it is understood that at the beginning of the reasons for deception are factors such as the attraction of World life, property, position, empty dreams, desires, seduction of the devil, and the purpose and goal that is motivated is to make a person forget Allah and the hereafter.

We see that words from the root "grr" including the word ğurūr, are more often mentioned in verses about worldly life. In examining these verses under certain headings in the order of nuzul of the surahs in which they are located, we gave priority to the verses in which the word gurür passes. These verse groups, which we give its Turkish mealsin our study text and the original texts in the bottom notes, consist of nine verses. Looking at all the verses and tafsir views that talk about the life of this world, Satan, infidels, hypocrites and wrongdoers, it seems that the word iurur in the verses is used in the sense of deception and deception. The opinions of the commentators about the exegesis of these verses are also collected in this mediocre. With in its general expression, it is understood that this meaning, which indicates a break in a person's perception of life and its associated state and operation, also corresponds to the root meaning of the word.

One of the words we examine under a separate heading is the word gharūr. The word garūr means very deceptive. The word is mentioned in a total of three verses. Due to its advanced deception characteristics, it is interpreted as the earth and the devil. the word gharūr is expressed in the verses as very deceptive with Allah. In particular, it is noted that Satan deceived people by telling the polytheists, "you are distinguished people, God will not take you to account," and he said to the believers, "God's Mercy is abundant, he will not punish you."

We tried to examine the verses in which words other than the root "grr" passed under two separate headings: "verses about worldly life" and "verses about general topics". seen that words derived from the root g-r-r are used in the sense of deception. In the verses that speak of the life of this world, it is warned that people should not be tempted by the life of this world and forget the hereafter, and that they should not be deceived by the game of temporary satisfaction. In the six verses collected under the title general topics, it is stated that a person should not fall into error about $\mathrm{Al}$ lah for all kinds of reasons, should not be deceived by the ostentatious lives of those who try to fight the verses of Allah, should not fall into empty dreams, and should not respect the misleading words and states of hypocrites.

Keywords: Tafsir, Gurūr, Qur'an, Hadith, Culture, Society, 
410 • Kur’ân'da Ġurūr Kelimesi ve “ğ-r-r” Kökünün Geçtiği Ayetler Üzerine Bir İnceleme

\section{GİRIş}

Kur'ân-1 Kerîm'in mû'ciz ve mûciz bir kitap olması hasebiyle ayetlerini oluşturan kelimelerin de lafız ve manaca bu kasamda değerlendirilmesi zarûreti vardır. Kur'ân'ı anlamada öncelikle ayetleri oluşturan kelimelerdeki dil inceliklerinin bilinmesi, sonra yer aldığı ayetin siyâk-sibâkı ve nüzul sebebi gibi temel hususların dikkate alınması gerektiği bilinir. Araştırmamızda bu temel hususlar dikkate alınarak Kur'ân-1 Kerîm'deki gurūr kelimesi ve "grrr" kökünün diğer türevleri geçtiği ayetler ele alınarak incelenmeye çalışılmıştır.

Genel çerçevesi itibariyle dünya hayatının konu alındığı söz konusu ayetlerde insanın kanma, kandırılma sonucu istikametini şaşırmasında rol oynayan etkenlerden bahsedilirken gurūr, garūr kelimelerinin ve "grrr" kökünden gelen diğer kelimelerin kullanıldığını görüyoruz. Ayetlerde ifadesini bulan hayat algısı ve insanın dünyaya geliş gayesindeki kırılmaların temelde aynı manaya gelen bu kökle ifade edilmesi özellikle kayda değer bir husus olmalıdır.

Çalışmada bu konuyu seçmemiz, hayatımızı derinden ve çok yönlü etkileyen gurur olgusunun açıklı̆ga kavuşturulması zarûretiyle ilgilidir. Arapça'dan Türkçeye geçen gurūr kelimesinin Türkçe yazı ve konuşma dilindeki kullanım hali de ayrı bir başlık altında kısaca ele alınarak uğradığı anlam değişikliği ve Türkçedeki kullanım hataları izah edilmeye çalışılmıştır.

Çalışmamız öncesinde yaptığımız araştırmalarda bu konuya özel yapılmış bir çalışmaya rastlayamadığımızı belirtmek isteriz. İlk dönem tefsir, lüğat ve terminoloji kaynaklarından itibaren yaptığımız taramalarda ulaşabildiğimiz bilgiler 1şığında konuyu işlemeye ve anlaşılır bir üslûpla sunmaya gayret sarf ettik. Ayet meallerini oluştururken muhtelif kaynaklardan yararlandığımız için kaynakçada meal kaynağı vermenin uygun olmayacağını düşündük.

\section{2. ĠURŪR KELIMMESİ}

\subsection{Gurūr Kelimesinin Etimolojik Yapısı ve Anlam Çerçevesi}

$\dot{G} r r$ kökünden gelen $\dot{g} u r \bar{r} r$ kelimesi, lügat kaynaklarında elbise ve deride meydana gelen kırllma, kıvrım- büklüm anlamındaki gar (غَ) müfredinin cem'i

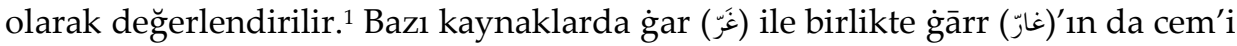

1 Ferâhîdî, el-Halil b. Ahmed, Kitâbu'l-'Ayn, thk. Abdulhamid Hindâvî (Beyrut: Dâru'lkütübü'l-ilmiyye, 1424/2002), 3/273; İbn Dureyd, Ebû Bekr Muhammed b. el-Hasen b. Du- 
olduğu ve bâtıl, boş şeyler anlamına geldiği belirtilir. ${ }^{2}$ Bunların yanı sıra kelime, sülasî mücerred birinci babtan garra (غَرَّ) fiilinin mastarı kabul edilerek kandırma, aldatma, ism-i mef' ûlu olan (مغرور) formu kandırılan, aldatılan kişi manalarında açıklanır. ${ }^{3}$ Mağūū kelimesi, kendisi tarafından aldatılan anlamına da gelmektedir. ${ }^{4}$ Başka bir görüşte ġarın temelde, herhangi bir tesirle bir şeyde meydana gelen ve cehalet, aldanma, eksilme, kırılma gibi sonuçlara götüren gaflet anlamına geldiği belirtilir. ${ }^{5}$

Kökün çok sayıda değişik formlarda farklı manalar taşıyan türevinin olduğunu görüyoruz. Bunlardan bazılarını şöyle sıralayabiliriz: Tehlike, belirsiz-

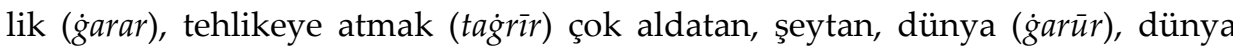

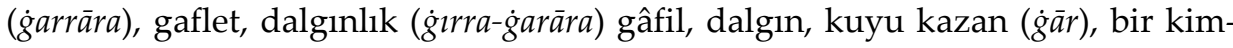
seyi zaaflarından yararlanarak aldatmak ( $\dot{g}$ ırra), iş bilmeyen, tecrübesiz toy genç ( $\dot{g}$ rr-g்arìr), namaz rükünlerindeki eksiklik, hafif uyku hâli, noksanlık, tarz-kalıp, kılıç ağzı, devede süt azalması, piyasalardaki darlık (ġırār), çuval (g்ırāra), kap, uzun boylu balık ( $\dot{g} \imath r a ̄ r a)$, bir şeydeki belirgin iz, beyaz başlı siyah su kuşu ( $\dot{g} u r)$, kefil, güzel ahlak (g்arir), ayın ilk üç gecesi (g்urar), köle, câriye, alındaki beyazlık, at alnındaki bir dirhemden büyü beyazlık, sahip olunan en değerli şey ( $\dot{g} u r-$ $r a)$, her haliyle güven veren saygın kişi, bir şeyin en beyazı, çok sıcak gün

reyd, Cemheretul'l-Lugga, thk. Remzī Munîr Be'albekî (Beyrut: Dâru'l-ilmi Ii'l-melâyîn, 1987), 1/124; Sâhib b. Abbâd, el-Muhîtfi'l-Lugga, thk. Muhammed Hasen Âl Yâsîn (Beyrut: Âlemu'lKütüb, 1994), 4/510; İbn Fâris, Ebû'l-Huseyn Ahmed b. Fâris, Mücmelü'l-Luğa, thk. Zuheyr Abdulmuhsin Sultan (Beyrut: Müessesetü'r-Risâle,1986), 3/681; Cevherî, İsmail b. Hammâd, es-Ṣıhâhh, thk. Ahmed Abdulğafur Attâr (Beyrut: Dâru'l-ilmi Ii'l-melâyîn, 1984), 2/767.

2 Zeccāc, Ebu İshak İbrahim b. es-Seriyy, Me 'âni'l-Kur'ân ve I'râbuh, thk. Abdulcelîl Abduh Şelebî (Beyrut: Âlemu'l-Kütüb,1988), 4/263. İbn Manzûr, Cemaleddin Muhammed b. Mükrrem, Lisânu'l-'Arab, thk. Abdullah Aliyyu'l-Kebîr, Muhammed Ahmed Hasbullah, Hâşim Muhammed eş-Şâzelî (Kahire: Dâru'l-Me'arif, ts.), 5/3232-3233; Fîrûzâbâdî, Mecduddīn Muhammed b. Yakub, el-Kâmûsu'l-Muhît, thk. Mektebetu tahkîki't-türâsi fî müesseseti'r-Risâle (Beyrut: Müessesetü'r-Risâle, 2005), 449; Zebîdî, Muhammed Murtadâ elHuseynî, Tâcu'l-'Arûs, thk. Mahmud Muhammed et-Tanâhî (Kuveyt: Vezâretu'l-i'lâm fi'lKuveyt, 1993), 13/216.

3 İsfahânî, el-Müfredâtu fì garî̉i'l-Kur'ân, er-Râgib el-İsfahânî, thk. Muhammed Seyyid Keylânî (Beyrut: Dâru'l-ma'rife, ts.), 358; İbn Manzûr, Lisânu'l-'Arab, 5/3232; Fîrûzâbâdî, elKâmûsu'l-Muhît, 449; Zebîdî, 13/214; Ahmed Muhtâr Omer, Mu'cemu'l-Luġati'l-'Arabiyyeti'lmu'âșıra (Kahire: Âlemu'l-kütüb, 1429/2008), 2/1604.

4 Ahmed Muhtâr Omer, Mu'cemu'l-Luğati'l-'Arabiyyeti'l-mu'âșıra, 2/1604.

5 Hasen el-Mustafavî, et-Tahkîk fì Kelimâti'l-Kur'âni'l-Kerîm, Kahire - Londra: Merkezu Neşr A sa r el-Allâme el-Mustafavî - Beyrut: Dâru'l-Kütübi'l-İlmiyye, 2009. 
(aǵarr), yer yüzeyindeki yarık, küçük nehir, deve otlatmak (g்ar), hoş kokulu beyaz bitki türü, Medîne-i Münevvere (g்arrā'), su yüzeyindeki kabarcıklar

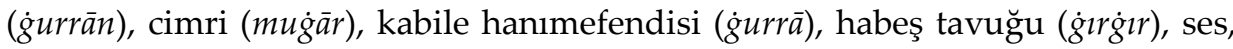
kaynama sesi, suyun boğazdaki gargara sesi (g்arğara) gibi kelimeler bu kökten türetilmiştir.6 Kelimelerin, kullanıldığı alana göre değişen manalarında kökün temeldeki kırılma anlamı ve buna bağlı sonuçlar arasında bir bağ olduğu görülmektedir.

Kaynaklarda, gurūr kelimesi; insanın, asılsız heveslerin oyununa gelme$\mathrm{si}^{7}$, insanın mal, makam, şeytan ve benzeri şeyler tarafından aldatılması ${ }^{8}$, kişinin kendini beğenmesi, başkalarının her halini ve yaptığı her şeyi küçümsemesi ve değersiz görmesi ${ }^{9}$ gibi birbirine yakın manalarda açıklanmaktadır. Diğer taraftan, çoğunlukla g -r-r kökünün manasını izah sadedinde müteradifi olan aldatmak anlamındaki h-d-' kelimesi kullanılmaktadır.

Bu tariflerde öne çıan ortak mananın, kişinin birtakım zaafları yüzünden normal halin dışına çıkması neticesinde maruz kaldığı aldanma, aldatılma olduğu, bunun da kelimenin kök anlamındaki kırılma, kıvrım-büklüm anlamıyla uyumlu düştüğü görülmektedir.

\section{KUR'ÂN ÖNCESİ DÖNEMDE ĠURŪR KELİMESİ ve Ġ-R- R KÖKÜNÜN KULLANIMI}

"Ġrr" kökünün, türevleriyle Câhiliye dönemi Arap şiirinde kullanıldığı görülmektedir. Muallakât şairlerinden Kinde kabilesine mensup İmrü̈lkays b.

6 Ferâhîdî, Kitâbu'l-'Ayn, 3/273-274; İbn Dureyd, Cemheretul'l-Luğa, 1/124; Sâhib b. Abbâd, elMuhîtfi'l-Luğa 4/510-511; İbn Fâris, Mucmelu'l-Lug̀a, 3/681-682; Cevherî, es-Ṣlhâh, 2/767-769; İbn Sîde, el-Muhkem ve'l-Muhîțu'l-A'ẓam, thk. Abdulhamîd Hindâvî, Beyrut: Dâru'lKütübi'l-ilmiyye, 2000; İsfahânî, el-Müfredâtu fí ġarîbi'l-Kur'ân, 358-359; İbn Manzûr, Lisânu'l-'Arab, 5/3232-3237; Fîrûzâbâdî, el-Kâmûsu'l-Muhît, 449-450; Feyyûmî, Ahmed b. Muhammed b. Ali el-Feyyûmî, el-Mișbâhu'l-munīr fî̀ garîbi'ş-şerḥı'l-kebîr, thk. Abdul'azîm eş-Şenâvî (Kahire: Dâru'l-maârif, ts.), 2/445; Zebîdî, Tâcu'l-'Arûs,13/214-237; Ahmed Muhtâr Omer, M'ucemu'l-Luğati'l-'Arabiyyeti'l-mu'âșıra, 2/1604-1605.

7 Beğavî, Ebû Muhammed el-Huseyn b. Mes'ûd el-Beğavî, Ma'âlimu't-Tenzîl, thk. Muhammed Abdullah en-Nemr-Osman Cum'a Dumeyriye-Süleyman Sâlim el-Hareş (Riyad: Dâru tayyibe, 1412.), 6/426.

8 Fîrûzâbâdî, Beșâiru zevi't-temyîz fî lețâifi'l-Kitâbi'l-Azîz, thk. Abdul'alîm et-Tahâvî (Kahire: Lecnetu İhyâ'i't-türâsi'l-İslâmî, 1973), 129; Munâvî, et-Tevkîif'alâ muhimmâti't-teâ'rîf, 201.

9 Mecmûa mine'l-müellifîn, Mu'cemu mușțalahâti'l-'ulûmi'ş-şer'i'iyye, 3/1176. 
Hucr (öl. 544 m.) beyitlerinde beyaz (garrā), beyazlar (ġurrān) kelimelerini kullanmıştır.10 Yine muallakât şairlerinden Tağlib kabilesine mensup Amr b. Külsûm (öl. 578 m.) şiirinde aldatıyor (yagurru), çok aldatan (garūr) kelimelerini kullanmıştır.11 Varaka b. Nevfel (öl. $592 \mathrm{~m}$.) bir beytinde sizi hiç kimse aldatmasın (felā yağrurküm aḥad) ifadesine yer vermiştir. ${ }^{12}$

Gurūr kelimesi kök ve türevlerinin Câhiliye dönemindeki taşıdığı anlamların Kur'ân'ın inişinden sonra da değişmediği, ayrıca Kur'ân'ın inişiyle birlikte anlam derinliği kazandığı anlaşılmaktadır.

\section{KUR'ÂN'DA ĠURŪR KELİMESİ ve ĠRR KÖKÜNÜN DİĞER TÜREVLERİ}

Kur'ân'da "ġrr" kökünün türevleri, gurūr kelimesiyle birlikte, dokuzu Mekkî, dördü Medenî olmak üzere on dört sûrede yirmi yedi yerde geçer. ${ }^{13}$ Araştırmanın bundan sonraki bölümünde söz konusu ayetler belli bir tasnife göre ele alınıp gurūr kelimesinin Kur'ân'daki yeri vuzûha kavuşturulmaya çalışılacaktır.

\subsection{Gurūr Formunun Yer Aldığı Ayetler}

Gurūr kelimesi, Kur'ân-1 Kerîm'de beşi Mekkî, dördü Medenî olmak üzere toplam dokuz ayette geçmektedir. Bu ayetler, nüzul tertibine göre şöyledir:

1) “Böylece (şeytan) ikisini de hîle ile aldattı. Ağacın meyvesini tattıklarında edep yerleri kendilerine göründü. Ve cennet yapraklarıyla üzerlerini örtmeye başladılar. Rableri onlara; ben size o ağacı yasaklamadım mı ve şeytanın size apaçık bir düşman olduğunu söylemedim mi, diye seslendi." (el-A'râf, 7/22.) Ayetin öncesindeki iki ayette şeytanın, Âdem ile Havvâ'yı; melek olacakları, ya da cennette ebediyen kalacakları gibi özendirici sözlerle yasaklı ağacın meyvesini yemeleri konusunda kandırmaya çalıştığı anlatılmış ve bu ayetin ilk

10 İmruülkays b. Hucr, Dîvânu Imruilkays, thk. Muhammed Ebu'l-Fadl İbrahim (Kahire: Dâru'l- Meârif, 2009), 83, 296.

11 Amr b. Ümmü Külsûm et-Tağlebî, Dîvân, thk. Eymen Meydan (Cidde: en-Nâdî'l-edebî essekâfî, 1992), 281.

12 Gassân Azîz Huseyn, Varaka b. Nevfel, asruh-hayâtuh-şi'ruh (Beyrut: Dâru'l-kütübi'l-ilmiyye, 1423/2002), 132.

13 Abdulbâkî, Muhammed Fuâd, el-Mu'cemu'l-müfehres li elfâẓı'l-Kur'âni'l-Kerîm (Beyrut: Dâru ihyâi't-turâsi'l-Arabî, ts.), 497. 
cümlesi olan fedellāhumā bi ġurūr ifadesiyle şeytanın hedefine ulaştığı belirtilmiştir. Ayetteki gurūr lafzı, tefsir kaynaklarında aldatma olarak açıklanmaktadır. ${ }^{14}$ Ayetin bütününe bakıldığında bu lafzın hileye dayalı bir aldatma olduğu açıkça görülmektedir.

2) “De ki: Allah’ı bırakıp da tapındığınız ve ona ortak koştuğunuz varlıklar üzerinde hiç düşündünüz mü? Gösterin bana bakalım, yeryüzündeki hangi nesneyi yaratmışlar? Yoksa onların göklerde mi ortaklığı var? Yahut biz onlara bir kitap vermişiz de onlar oradaki kesin bir delile mi dayanmaktalar? Doğrusu, o zalimlerin birbirlerine vaatleri aldatmacadan başka bir şey değildir." (Fâtır, 35/40) Buradaki ayetin son cümlesinde geçen gurūr kelimesi tefsirlerde içi boş, aldatmaca, yalan, asılsız şey karşılıklarıyla açıklanmaktadır. ${ }^{15}$ Buna göre, zalim olarak vasıflandırılan müşriklerin birbirlerine olan vaatlerinin kendilerini avutmaktan, kandırmaktan öteye geçmeyen asılsız şeyler olduğu ifade edilmiş olmaktadır. Bazı müfessirler ayetin son kısmını, müşrik seçkinlerinin alt tabakası olarak gördükleri kimselere; "Bu tanrılar sizleri Allah'a yaklaştıracak." şeklindeki telkinleri16 veya bizzat kendilerinin onlar için Allah'a şefaatçi olacakları yolundaki vaatleri olarak yorumlamaktadır. ${ }^{17}$

3) “Haydi, onlardan gücünün yettiklerini çağrınla ayart, atlıların ve piyadelerinle onlara karşı ordu topla; mallarına, evlatlarına ortak ol, kendilerine vaatte bulun. Zaten şeytan onlara aldatmadan başka bir şey vaat etmez (el-İsrâ, 17/64). Müfessirlerin buradaki gurūr kelimesini de içi boş, aldatmaca, yalan, asılsız şey manasında yorumladıkları görülmektedir. ${ }^{18}$

14 Mukâtil b. Süleyman, Tefsîru Mukâtil b. Süleymân, thk. Abdullah Mahmud Şahâta (Beyrut: Dâru't-târîhi'l-Arabî,1423/2002), 2/32; Taberî, Ebû Ca'fer Muhammed b. Cerîr. Câmi'u'lBeyân 'an te'vîl-i 'Âyi'l-Kur'ân. Thk. Abdullah Abdulmuhsin et-Türkî (Kahire: Dāru Hecr, 2001), 10/110; İbn Ebî Hâtim, Abdurrahman b. Muhammed b. İdrîs, Tefsîru'l-Kur'âni'l'Azîim, thk. Es'ad Muhammed et-Tayyib (Mekke \& Riyad: Mektebetu Nizâr Mustafa el-Bâz, 1997), 5/1451.

15 Mukâtil b. Süleyman, Tefsîru Mukâtil b. Süleymân, 3/560; Taberî, Câmi'u'l-Beyân 'an Te'vîl-i 'Âyi'l-Kur'ân, 19/390; Beğavî, Ma'âlimu't-Tenzîl, 6/426.

16 Kurtubî, Ebû Abdillah Muhammed b. Ahmed b. Ebî Zekeriyyâ. el-Câmi'uliAhkâmi'lKur'ân.Thk. Abdullah b. Abdulmuhsin et-Türkî (Beyrut: Müessetü'r-risâle, 2006), 27/394.

17 Beydâvî, Nâsıruddin Ebu Said Abdullah b. Omer.Envâru't-Tenzîl ve Esrâru't-Te'vîl, thk. Muhammed Subhī Hasen Hallâk, Mahmud Ahmed el-Atraş (Beyrut: Dâru'r- reşîd Müessesetü'l-îmân, 2000), 3/124.

18 Mukâtil b. Süleyman, Tefsîru Mukâtil b. Süleymân, 2/540; Taberî, Câmi'u'l-Beyân 'an Te'vîl-i 'Âyi'l-Kur'ân,14/666; Mâturîdî, Ebu Mansur Muhammed b. Muhammed el-Mâturîdî, Te 'vîlâtu'l-Kur 'ân, thk.Halil İbrahim Kaçar (İstanbul: Mizan Yayınevi, 2006), 8/319. 
4) “Böylece biz, her peygambere insan ve cin şeytanlarını düşman kıldık. Bunlar aldatmak için birbirlerine yaldızlı sözler fısıldarlar. Rableri dileseydi bunu yapamazlardı. Artık onları uydurdukları şeylerle baş başa bırak (elEn'âm, 6/112). Ayet metnindeki zuhrufe'l-kavli ġurūran ifadesini müfessirler; esasa dayanmayan, kandırma maksatlı ve dinleyenin ilgisini çekecek süslü, yaldızlı söz ve vaatlerle aldatma olarak açıklamaktadırlar. ${ }^{19}$ İbn Ebî Hâtim'e (öl. 327/939) göre bu yapıdaki kişiler, birbirlerini fitnede kendi tarafına çekmek için yaldızlı kelimelerle konuşma yöntemini kullanırlar.20 Râzî (öl. 606/1519), bu aldatılma olayını ya tamamen cehaletten ya da cehaletten kaynaklanan bir durum olarak değerlendirir ${ }^{21}$.

5) “Rahman’a karşı size yardım edecek askerleriniz hani, kimler? Kâfirler ancak derin bir aldanış içindedirler."(el-Mülk, 67/20) Ayet metninin sonundaki gurūr kelimesinin ne manaya geldiği sorulan İbn Abbas; bâtıl yani boş, asılsız ve hakikatle ilgisi olmayan cevabını verir. ${ }^{22}$ Müfessirlerin de kelimeye burada aynı manayı verdiğini görüyoruz. ${ }^{23}$

6) “Herkes ölümü tadacaktır. Yaptıklarınızın karşılığı sizlere eksiksiz olarak ancak kıyamet gününde verilecektir. Kim cehennemden uzaklaştırılır da cennete alınırsa artık kurtulmuştur. Dünya hayatı zaten aldatıcı şeylerden ibarettir." (Âl-i İmrân, 3/185) Buradaki gurūr kelimesi de müfessirlere göre, değersiz, geçici'i24, boş şeylere özendirerek aldatan ${ }^{25}$ manalarına gelmektedir. İbn Âşûr (öl. 1393/1973) önceki ayetlerle bağlamı dolayısıyla bu ayetle, Hz. Peygamber ve müminlere Uhud savaşında yaşananlarla ilgili teselli verildiğini ve görüşümüz

19 Mucâhid b. Cebr, Tefsìru Mucâhid, thk. Muhammed Abdusselâm Ebu'n-Nîl (Kahire: Dâru'lFikri'l-İslâmî el-Hadîse, 1989), 327; Taberî,Câmi'u'l-Beyân 'an Te'vîl-i 'Âyi'l-Kur'ân,9/497; Mâturîdî, Ebu Mansûr Muhammed b. Muhammed el-Mâturîdî, Te 'vîlâtu'l-Kur 'ân, thk. Ertuğrul Boynukalın, muraca 'a. Bekir Topaloğlu, 5/186.

20 İbn Ebî Hâtim, Tefsîru'l-Kur'âni'l-'Azîm, thk. Es'ad Muhammed et-Tayyib (Mekke \& Riyad: Mektebetu Nizâr Mustafa el-Bâz, 1997), 4/1372.

21 Râzî, Muhammed er-Râzî Fahreddîn b. Allâme Ziyâeddîn Ömer, Mefâtîhư'l-ġayb (BeyrutLübnan: Dâru'l-fikr, 1401/1981), 13/163.

22 Merkezü'd-dirâsât ve'l-ma'lûmâti'l-Kur'âniyye, el-Medhal ilâ mevsûati't-tefsîri'l-me'sûr (Beyrut: Dâr İbn Hazm, 1439/2017), 22/79.

23 Mukâtil b. Süleyman, Tefsîru Mukâtil b. Süleymân, 4/392.

24 Mukâtil b. Süleyman, Tefsîru Mukâtil b. Süleymân, 1/320.

25 Vâhidî, Ebû'l-Hasen Ali b. Ahmed b. Muhammed, et-Tefsîru'l-Basîț, thk. Nûra bint Abdulazîz el-Versân (Riyad: Câmiatu İmam Muhammed b. Suûdel-İslâmiyye-İmâdetu'l-Bahsi'lİlmî, 1430), 18/194; Kurtubî, el-Câmi'uli Aḥkâmi'l-Kur'ân,17/96. 
alınsaydı savaşa çıkılmaz ve bunlar başa gelmezdi şeklindeki münafık iddialarının boşa çıkarıldığını belirtir. ${ }^{26}$

7) "Yine o zaman münafıklar ve kalplerinde hastalık bulunanlar: Allah ve Resûl'ünün vaatleri bizleri aldatmaktan ibaretmiş diyorlardı." (el-Ahzâb, 33/12.) İslam âlimleri Hendek savaşı hazırlıkları sırasında geleceğe dâir fetih müjdeleri içeren bazı mucizelerin meydana geldiğini dile getirmişlerdir. Hz. Peygamber bu müjdeleri duyurunca, savaşın şiddetli evrelerinde münafıklardan Muattib b. Kuşeyr; üzerimize gelen oklardan tuvalet ihtiyacımızı bile görmeye firsat bulamazken Muhammed bize Yemen, İran ve Bizans'ın fethini vaat ediyor, vallahi bu bir aldatmacadır/ğurūr demiş ve ayet bunun üzerine inmiştir. ${ }^{27}$

8) "Onlara durmadan vaat eder, boş ümitler verir. Şeytanın onlara vaatlerde bulunması aldatmadan başka bir şey değildir." (en-Nisâ, 120) Bu ayetteki gurūr kelimesi de boş, bâtıl, hileli aldatma manalarına alınmaktadır. ${ }^{28}$ Râzî, bu ayetin tefsirinde gurūr'u; insanın bir şeyi faydalı ve tatlı zannetmesi, sonra o şeyin ne büyük bir belâ ve acı olduğunu anlaması olarak tanımlar ve dünya ahvâlinin de bütünüyle böyle olduğunu söyler. ${ }^{29}$

9) "Dünya hayatı, aldanış metâından başka bir şey değildir." (el-Hadîd, 57/20) Tefsirlerde, ayetteki metāu'l-g்urūr ifadesiyle vurgulanan aldanışın, âhireti unutup sadece dünya için çalışan veya geçici yararlanmayı gözlerinde fazla büyütenlerle ilgili olduğu belirtilir. ${ }^{30}$ Mukâtil b. Süleyman (öl. 150/767) buradaki gurūr kelimesini, fânî olarak yorumlar ve manayı kısa bir süre yararlanılan ve sonra terk edilen metâ olarak açıklar. ${ }^{31}$

Gurūr kelimesinin geçtiği ayetlerin bütününe ve müfessirlerin görüşlerine bakıldığında kelimede öne çıkan mananın aldatma, aldanma olduğu görülmektedir. Bu da Kur'an'ın ğurur kelimesine lügat ve istılah anlamı dışında başka bir anlam yüklemediğini göstermektedir.

26 İbn Âşûr, Muhammed et-Tâhir, et-Tahrîrve't-Tenvîr (Tunus: ed-Dâru't-Tûnisiyye li'n-neşr, 1984), 21/283; Vâhidî, et-Tefsìru'l-Basìt, 1430), 18/194.

27 Mukâtil b. Süleyman, Tefsîru Mukâtil b. Süleymân, 3/478.

28 Mukâtil b. Süleyman, Tefsîru Mukâtil b. Süleymân, 1/408.

29 Râzî, Mefâtîhu'l-g்ayb, 11/51.

30 Vâhidî, et-Tefsîru'l-Basît, 21/302; İbn Atıyye, Ebu Muhammed Abdülhak b. Galib b. Atryye el-Endülüsî, el-Muharrerü'l- vecîz fĩ tefsîri'l-Kitâbi'l-'Azîz, thk. Abdüsselâm Abdüşşâfî Muhammed (Beyrut: Dârü'l- kütübi'l-ilmiyye, 1422/2001), 8/235.

31 Mukâtil b. Süleyman, Tefsîru Mukâtil b. Süleymân, 4/243. 


\subsection{Garāur Kelimesinin Yer Aldığı Ayetler}

Ġarūr (غَرور) kelimesi, fa ūl vezninde mübâlağalı ism-i fâil olup, çok aldatan manasına gelmektedir. ${ }^{32}$ Yer aldığı ayetlerde farklı anlamlar taşıdığ 1 için çalışmamızda ayrı bir başlık altında incelemeyi uygun bulduk. Kelime, Kur'ân-1 Kerîm'de ikisi Mekkî, biri Medenî olmak üzere toplam üç ayette geçmektedir. Ayetleri, bulundukları sûrelerin nüzul tertibine göre şöyle sıralayabiliriz:

1) “Ey insanlar! Allah'ın va'di haktır; dünya hayatı sakın sizleri aldatmasın, o çok aldatan da/ġarūr sizleri sakın Allah ile kandırmasın." (el-Fâtır, 35/5) Müfessirler, ayetteki çok aldatan ifadesiyle kastedilenin; daima saptırma, aldatma peşinde olduğu gerçeğiyle ilişkilendirerek şeytan olduğunu ifade ederler. ${ }^{33}$ İbn Âşûr ayetin, biri cazibeli görüntülere kapılarak kendi kendini aldatmak, diğeri şeytan tarafından aldatılmak şeklinde iki türlü aldanma halini içerdiğini, ikincisinin daha tehlikeli olduğunu belirtir. ${ }^{34}$ Şeytanın Allah ile aldatmasını müfessirler; muhatap müşrik kitlenin seçkin insanlar olmaları dolayısıyla Allah'ın onları sorgulamayacağı yolundaki aldatan vesveseleri ve Allah adına asılsız vaatleri şeklinde yorumlamaktadır. ${ }^{35}$

2) “Ey insanlar! Rabbinize saygısızlıktan sakının; hiçbir babanın evladından fayda göremeyeceği, evladın da babasından hiçbir fayda göremeyeceği bir günden korkun. Allah'ın vaadi haktır. Sakın dünya hayatı sizleri aldatmasın; o çok aldatan da sizleri sakın Allah ile kandırmasın." (Lokman, 31/33) Bu ayetteki çok aldatan anlamına gelen ġarūr kelimesi, şeytan, dünya, insan ve insanı aldatan her şey olarak açıklanıyor. ${ }^{36}$ Kurtubî (öl. 671/1273), bütün işi insanı sonu gelmez hayallerle avutmak, ahiretini unutturmaya çabalamak olduğu için kastedilenin şeytan olduğunu söyler. ${ }^{37}$ Râzî'ye göre kastedilen öncelikle dünyadır, emredilen de onun cazibeli ahvâline kapılmamalarıdır ve nefs-i emmâre ile

32 Ahmed Muhtâr Omer, Mu'cemu'l-Lugiati'l-'Arabiyyeti'l-mu'âștra, 2/1606.

33 Mukâtil b. Süleyman, Tefsîru Mukâtil b. Süleymân, 3/552; Taberî, Câmi'u'l-Beyân 'an Te'vîl-i 'Âyi'l-Kur'ân, 19/330;ỉbn Atıye, el-Muharrerü'l-vecîz fî tefsîri'l-Kitâbi'l-'Azîz, thk. Abdüsselâm Abdüşşâfî Muhammed, 7/203.

34 İbnÂşûr, et-Tahrîrve't-Tenvîr, 22/257.

35 Taberî, Câmi'u'l-Beyân 'an Te'vîl-i 'Âyi'l-Kur'ân, 19/330; Kurtubî, el-Câmi'u li Ahkâmi'l-Kur'ân, $17 / 346$.

36 Mukâtil b. Süleyman,Tefsîru Mukâtil b. Süleymân, 3/440; Taberî, Câmi'u'l-Beyân 'an Te'vîl-i 'Âyi'l-Kur'ân, 18/582.

37 Kurtubî, el-Câmi'u li Aḥkâmi'l-Kur'ân, 16/496. 
şeytanın; "bu hayatın tadını çıkarmaya bakın, tövbe edersiniz, Allah ahiretinizi de böyle yapar" şeklindeki aldatmasına gelmemeleridir. ${ }^{38}$

3) "Münafıklar onlara; bizler sizlerle beraber değil miydik diye seslenirler. Onlar; evet, öyleydi, ama sizler kendinizi fitneye düşürdünüz, fırsat kolladınız, hep şüphe içinde oldunuz, Allah'ın emri (ölüm) gelinceye kadar boş ümitler, arzular sizleri aldattı ve o çok aldatan da sizleri Allah ile kandırdı." Bu ayetteki çok aldatan anlamına gelen garūr kelimesinin, önceki iki ayette olduğu gibi şeytan ve dünya manalarında açıklandığını görüyoruz. ${ }^{39}$ Zeccâc (öl. 311/924), gā̄r kelimesinin az veya çok aldatan için kullanılabileceğini, ama garūr'un az aldatan için kullanılamayacağını söyler. ${ }^{40}$ Şinkîtî (öl. 1913), ayette şeytanın garūr kelimesiyle tabir edilmesini, onun türlü telkinlerle insanları devamlı kandırma çabalarına bağlar. ${ }^{41}$ Şinkîtî ayrıca, Allah ile aldatmadan muradın ne olduğunu aynı ayetin baş kısmının açıkladığını, bunun da şeytanın, Allah'ın öldükten sonra tekrar diriltme vaadinin gerçekleşmeyeceği şeklindeki telkini olduğunu belirtir. ${ }^{42}$

Bu üç ayetteki çok aldatan manasına gelen $\dot{g} a r \bar{u} r$ kelimesinin faū’l vezninde ma'rife bir isim olarak yer alması, böyle bir işi ancak şeytan gibi aldatmada usta birinin yapabileceğini göstermektedir. Kelimenin ifade ettiği mana ve müfessirlerin yorumları da bu düşünceyi desteklemektedir. Ayrıca, Allah ile aldatmanın tehlikeli sonuçlara yol açan bir eylem olduğunu, bunun da kişinin dünyanın ve nefsin oyununa gelmesi veya şeytanın türlü şekillerdeki saptırma oyunlarının neticesi olarak gerçekleştiği söylenebilir.

38 Râzî, Mefâtîhu'l-g்ayb, 25/165.

39 Mukâtil b. Süleyman, Tefsîru Mukâtil b. Süleymân, 4/240; Taberî, Câmi'u'l-Beyân 'an Te'vîl-i 'Âyi'l-Kur'ân, 22/406; Mâverdî, Ebu'l Hasen Ali b. Muhammed b. Habîb el-Mâverdî, enNüket ve'l-'Uyûn, thk. Esseyyid b. Abdulmaksûd b. Abdurrahîm (Beyrut: Dâru'l-kütübi'lilmiyye, ts.), 5/476.

40 Zeccâc, Ebu İshak İbrahim b. es-Seriyy, Me 'ânî'l-Ḳur'ân ve i râbuh, thk. AbdulcelîlAbduhŞelebî (Beyrut: Âlemu'l-Kütüb,1988), 5/125.

${ }^{41}$ Şinkîtî, Muhammedü'l-Emin, b. Muhammed, Edvâu'l-Beyân fî̀ ị̂âhi'l-Kur'âni bi'l-Kur'ân, nşr. Vakfu müesseseti Süleyman b. Abdilazîz er-Râcihî el-hayriyye (Cidde: Dâru âlemi'l-fevâid, ts.), $7 / 867$.

42 Şinkîtî, Eḍ̂â'l-Beyân fî̀ ị̂âhi'l-Kur'âni bi'l-Kur'ân, 7/868. 


\section{5. $\dot{G}-R-R$ KÖKÜNDEN GELEN DİĞER KELIMMELERİN GEÇTIĞİ AYETLER}

\subsection{Dünya Hayatıyla İlgili Ayetler}

Çalışmamızın bu kısmında, öncelikle konu birliği bakımından ağırlıkta olan ayetleri bir arada ele almayı uygun buluyoruz. Dünya hayatıyla ilgili olan bu ayetleri yer aldıkları sûrelerin nüzul tertibine göre şöyle sıralayabiliriz:

1) "Bu azap, ayetlerimizi alay konusu yapmış olmanız ve dünya hayatının sizleri aldatmış olması sebebiyledir. O gün artık oradan çıkarılmazlar, mazeretleri de kabul edilmez." (el-Câsiye, 45/35) Müfessirlere göre dünya hayat1nın aldatması, cazibeli görüntüsüyle insanlara ahireti yok sayma derecesinde unutturması veya tamamen inkâra sürüklemesi anlamına gelir. ${ }^{43}$ İbn Âşûr, ayette aldatma eyleminin hayata isnadını, hayatın aldatma-aldanma yol ve sebeplerini en geniş çerçevede içinde barındırmasına bağlar ve bunu mecazi bir anlatım olarak yorumlar. ${ }^{44}$

2) "Dinlerini bir oyuncak ve eğlence edinen, dünya hayatının aldattığ 1 kimseleri bırak." (el-En'âm, 6/70) Mâverdî'ye (öl. 450/1058) göre dünya hayatının aldatması, ya kişinin arzularının yerine gelmesiyle hayatın aldatması, ya da böyle bir hayata özendiren dünyanın aldatması şeklinde anlaşılır. ${ }^{45}$ İbn Atıye (öl. 541/1147) kuş, ağzındaki azıkla yavrusunun ağzını doldurdu manasındaki ġarra't-țāiru ferhhahū örneğini vererek ayetteki ġarrathumu'l-hayāti'd-dunyā ifadesini, dünya onların ağızlarını doldurdu ve doyurdu şeklinde yorumlar. ${ }^{46}$

3) “(...) Dünya hayatı onları aldattı ve kâfir olduklarına dair kendi aleyhlerine şahitlik ettiler." (el-En'âm, 6/130) Mâverdî, buradaki dünya hayatının aldatmasını; dünya hayatının cazibeli haliyle aldatması, ya da üstünlük arzulariyla aldatması veya firsatların tanınmasıyla aldatması şeklinde anlamak gerektiğini ifade eder. ${ }^{47}$ Bazı müfessirlerce, ayetteki "dünya hayatının aldattığı" ifadesi kâfirlerin, içinde bulundukları küfür halinin akılla bağdaşmayan kötü bir

43 Taberî, Câmi'u'l-Beyân 'an Te'vîl-i 'Âyi'l-Kur'ân, 21/109; Kurtubî, el-Câmi'u li Ahkâmi'l-Kur'ān, 19/173; Ebussuûd b. Muhammed el-İmâdî, İrșâdu'l-'akli's-Selîm ilâ mezâye'l-Kitâbi'l-Kerîm, thk. Abdulkadir Ahmed Atâ' (Riyad: Mektebetu'r-Riyadı'l-hadîse, ts.), 5/119.

44 İbnÂşûr, et-Tahrîrve't-Tenvîr, 25/376.

45 Mâverdî, en-Nüket ve'l-'Uyûn, 2/130.

46 İbn Atıyye, el-Muharrerü'l-vecîz fî tefsîri'l-Kitâbi'l-'Azîz, 3/387.

47 Mâverdî, en-Nüket ve'l-'Uyûn, 2/171. 
aldanma olduğu anlamında güçlü bir kınama içerdiği gibi, dünya hayatının ağızlarını doldurup doyurdukları manasına da gelir ${ }^{48}$ şeklinde yorumlanmaktadir.

4) “Onlar ki, dinlerini eğlence ve oyun edindiler ve dünya hayatı onları aldattı. Onlar bu günlerine ulaşacaklarını unuttukları ve ayetlerimizi bile bile inkâr ettikleri gibi biz de bugün onları unuturuz." (el-A'râf, 7/51) Mâturîdî (öl. 333/944) aldatmanın dünya hayatına izafe edilmesini hayatın aldatan etkenlerle dolu oluşuna bağlar. ${ }^{49}$ Râzî, bu ayetin tefsirinde, dünya hayatının aldatması ifadesinin mecazî olduğunu, gerçekte aldatanın hayatın içinde yaşananlar olduğunu, insanın mal-mülk, makam peşine düşmek, daha müreffeh ve daha uzun yaşamak gibi doymak bilmez hırslara kapılarak dini bırakıp büsbütün dünyaya daldığını ve bütün bunların insanı oyuna getirip aldattığını ifade eder. ${ }^{50}$

5) "Sakın dünya hayatı sizleri aldatmasın, o çok aldatan da sizleri Allah ile kandırmasın." (Lokmân, 31/33) Bu ayet garūr lafzı dolayısıyla yukarıda geçtiği için burada son kısmına yer verdik. Mâturîdî, bir önceki ayetle ilgili yorumuna ilaveten bu ayetteki aldatmanın cazibeli görüntüsüyle doğrudan dünya tarafından olabileceği manasının da anlaşılabileceğini ifade eder. ${ }^{51}$ Mâverdî'ye göre bu ayetteki dünya hayatı aldatması; intikamın geciktirilmesi sizleri yanıltmasın ve mal-mülk sizleri İslâm'a karşı aldatmasın şeklinde iki türlü yorumlanabilir. ${ }^{52}$

6) "Ey insanlar! Allah'ın vaadi haktır; Dünya hayatı sakın sizleri aldatmasın, o çok aldatan da sizleri sakın Allah ile kandırmasın." (Fâtır, 35/5) Taberî (öl. 310/923) buradaki dünya hayatının aldatmasından maksadın, insanların içinde bulundukları zenginliğe ve kendilerince seçkin konumlarına aldanmalarıdır. ${ }^{53}$ İbn Âşûr'a göre ayette aldatmanın dünya hayatına isnadı, fiilin sebebine isnadı kabilinden mecazî bir ifade olup, insanı asıl aldatan, dünya hayatının cazibesine kapılan kendisidir. ${ }^{54}$

48 İbnAtiyye, el-Muharrerü'l-vecîz fì tefsîri'l-Kitâbi'l-'Azîz, 3/463; Râzî, Mefâtîhuh'l-ġayb, 4/226.

49 Mâturîdî, Te 'vîlâtu'l-Kur'ân, thk. Ertuğrul Boynukalın, 5/99.

50 Râzî, Mefâtîhu'l-g்ayb, 24/99.

51 Mâturîdî, Te 'vîlâtu'l-Kur'ân, thk. Ali Haydar Ulusoy, 11/257;

52 Mâverdî, en-Nüket ve'l-'Uyûn, 4/349.

53 Taberî, Câmi'u'l-Beyân 'an Te'vîl-i 'Âyi'l-Kur'ân, 19/331.

54 İbn Âşûr, et-Tahrîr ve't-Tenvîr, 22/258. 


\subsection{Genel Konulardaki Ayetler}

Bu ayetleri, yer aldıkları sûrelerin nüzul tertibine göre şöyle sıralayabiliriz:

1) "Ey insan! Kerîm Rabbinle ilgili seni ne yanıltıp aldattı?" (el-İnfitâr, 82/6) Mukâtil b. Süleyman bu ayetin; şaşı gözlü, zorba Eşed b. Kilde'nin; “Eğer cennet kapısının kulpunu bir yakalarsam, onu kuvvetle tutup pek çok insanın oraya girmesini sağlayacağım" sözleri üzerine nazil olduğunu, bu sözüyle şeytanın oyununa geldiğini ve Mekke'nin fethedildiği gün öldürüldüğünü söyler. ${ }^{55}$ İbn Ebî Hâtim; bu ayeti okuyan Hz. Ömer'in; "vallâhi onu cehaleti aldattı" dediğini zikreder. ${ }^{56}$

2) "Kâfirlerden başkası Allah'ın âyetleri hakkında tartışmaya girmez. Onların beldeler arasında dolaşmaları seni aldatmasın." (Mü'min, 40/4) Tefsirlerde, buradaki hitabın Hz. Peygamberin şahsında dönemin sıkıntılı şartlarında yaşayan mü'minlere yönelik olduğu, Mekke müşrikleri kastedilerek kâfirlerin refah içinde ve rahatça beldeler arasında dolaşmaları, seyahat veya ticaret için değişik bölgelere gidip gelmeleri sizleri yanıltıp aldatmasın uyarısında bulunulduğu ifade edilir. ${ }^{57}$

3) “O sıra münafıklar ve kalplerinde hastalık olanlar; bunları, dinleri aldattı diyorlardı. Hâlbuki kim Allah'a tevekkül ederse (bilir ki) O Azîz ve Hakîmdir." (Enfâl, 8/49) Abdurrezzâk (öl. 211/826-27) bu kişilerin Bedir savaş1na katılmayan bir münafıklar grubu olduğunu söylerken, diğer taraftan Kelbî'nin; bunların İslâm'ı kabul ettikleri halde müşrikler safında Bedir savaşına katılan bir grubun, müminlerin sayıca azlığını görünce bu sözü söylediklerini belirtir. ${ }^{58}$ Ayette sözü edilen kalplerdeki hastalıktan murâdın küfür olduğunu belirten Mukâtil b. Süleyman, bu âyetin, hicret etmeyip Mekke'de müşriklerle birlikte yaşamaya devam eden bir grup Müslümanın müşrikler safında katıldıkları Bedir savaşında müminleri sayıca az görmeleri üzerine dinlerinde şüpheye düştüklerini ve Hz. Peygamberin ashâbını kastederek, dinlerinin onları aldattığ1 şeklindeki sözleri üzerine bu âyetin indiğini söyler. ${ }^{59}$ Taberî̀ye göre

55 Mukâtil b. Süleyman, Tefsîru Mukâtil b. Süleymân, 4/613.

56 İbn Ebî Hâtim, Tefsîru'l-Kur'âni'l-'Azî̀m, 10/3408.

57 Mukâtil b. Süleyman, Tefsîru Mukâtil b. Süleymân, 3/705; Taberî, Câmi'u'l-Beyân 'an Te'vîl-i 'Âyi'l-Kur'ân, 20/280; Mâturîdî,Te'vîlâtu'l-Kur'ân, thk. Mürteza Bedir, 13/10.

58 Abdurrezzâk b. Hemmâm es-San ânî, Tefsîru'l-Kur'ân, thk. Mustafa Muslim Muhammed, Riyad: Mektebetu'r-Ruşd, 1989. 1/260-261.

59 Mukâtil b. Süleyman, Tefsîru Mukâtil b. Süleymân, 2/120-121. 
bunlar, müşrikler arasında İslâm'a yakınlık duyan, ama tam olarak gönüllerinde hissetmeyen ve müşriklerin yanında katıldıkları Bedir savaşında müminlerin sayıca az olduğunu görmeleri üzerine bu sözü söyleyen bir gruptur. ${ }^{60}$ Mâverdî, İbn Abbas ve Mücâhid'e dayandırarak aynı yorumda bulunurken, ayrıca Hasan-1 Basrî'nin görüşüne yer vererek bunların doğrudan müşrikler olabileceğini de söyler. ${ }^{61}$

4) "Münâfıklar onlara; bizler sizlerle beraber değil miydik, diye seslenirler. Onlar; evet, öyleydi, ama sizler kendinizi fitneye düşürdünüz, fırsat kolladınız, hep şüphe içinde oldunuz, Allah'ın emri (ölüm) gelinceye kadar boş ümitler, arzular sizleri aldattı ve o çok aldatan da sizleri Allah ile kandırdı." (elHadîd, 57/14) Ayette ifade edilen aldatan boş ümitlerin, arzuların tefsirlerde; “ Menfaat beklentileri, Hz. Peygamberin yakında ölebileceği veya herhangi bir şekilde ortadan kaldırılabileceği, böylece İslam'dan kurtulup rahatlayacakları"62 şeklinde açıklandığını görüyoruz. Bunların şeytan, dünya, mağfiret ümidi veya bugün-yarın manalarına geldiği de ifade edilir. ${ }^{63}$ Başka bir yoruma göre müşriklerin, müminlerin başına türlü felâketlerin gelmesi beklentileridir. ${ }^{64}$

5) "Onların bu tutumu; sayılı günler dışında bize ateş asla dokunmayacak demelerinden ötürüdür. Uydura geldikleri yalanlar dinleri hakkında kendilerini aldatmıştır." (Âl-i İmrân, 3/24) Müfessirlere göre Yahudilerin; cehennemde ancak, atalarının buzağıya tapma süresi olan kırk gün azap görecekleri veya kendilerinin Allah'ın oğulları ve sevgilileri oldukları iddiaları üzerine, Allah bunun kendilerini aldatan bir iftira olduğunu bildirmektedir. ${ }^{65}$

6) "Kâfirlerin beldelerde dolaşmaları sakın sizleri aldatmasın." (Âl-i İmrân, 3/196) Ayetin müşrik Araplar hakkında indiğini belirten Mukâtil b. Süleyman, buradaki hitabın Hz. Peygambere olduğunu, bir sonraki ayette de ifade edildiği gibi onların belde belde dolaşıp kazandıkları malların gerçekte pek de değerli olmadı ̆̆ı, onların ahiretteki yerlerinin cehennem, müminlerin ise cennet

60 Taberî,Câmi'u'l-Beyân 'an Te'vîl-i 'Âyi'l-Kur'ân, 11/227.

61 Mâverdî, en-Nüket ve'l-'Uyûn, 2/325-326.

62 Mukâtil b. Süleyman, Tefsîru Mukâtil b. Süleymân, 4/240; Mâturîdî, Te'vîlâtu'l-Kur'ân, 14/349-350.

63 Mâverdî, en-Nüket ve'l-'Uyûn, 5/475.

64 Zeccâc, Ebu İshak İbrahim b. es-Seriyy, Me 'ânî'l-Kur 'ân ve i 'râbuh, 5/124.

65 Mukâtil b. Süleyman, Tefsîru Mukâtil b. Süleymân, 1/269; Taberî, Câmi'u'l-Beyân 'an Te'vîl-i 'Âyi'l-Kur'ân, 5/297; Zeccâc, Me 'ânîl'l-Kur'ân ve i 'râbuh, 1/392. 
olacağ1 yorumunda bulunur. ${ }^{66}$ Aynı yorumda bulunan Taberî, Hz. Peygamber'in böyle bir konuda aldatılması mümkün olmadığından gerçekte bu hitabın bütün müminlere olduğunu belirtir. ${ }^{67}$ Müfessirlerin bu minval üzere görüş beyan ettikleri görülürken, Ferrâ (öl. 207/822), ayetteki kâfirlerden murâdın Yahudi tâcirler olduğ ${ }^{68}$, Zeccâc da hitabın Hz. Peygamber'e ve herkese olduğunu ifade ederler. ${ }^{69}$ Mâverdî'nin yorumu da şöyledir: “Peygamber (s.a.v.)'in aldanması câiz görülmediğine göre, böyle bir hitaba nasıl muhatap olduğu sorusu akla gelebilir. Bunun iki türlü cevabı vardır: 1)Allah Teâla te'dîp ve tahzîr için O'na bu hitapta bulunmuştur. 2) Bu hitap, hitabı duyan herkesedir. Allah, sanki: ey duyan-işiten herkes; kâfirlerin belde belde dolaşmaları sizleri yanıltıp aldatmasın. Dolaşma maksatlarıyla ilgili iki görüş vardır: 1) Dolaştıkları beldelerin nimetlerinden yararlanmak, 2) Günahlarının cezası henüz verilmemişken hayatın tadını çıarmak."70 Mâverdî'nin yorumunun daha kapsayıcı ve diğer yorumları tamamlayıcı mahiyette olduğu görülüyor.

\section{HADÎS-İ ȘERÎFLERDE ĠURŪR KELİMESİ ve Ġ-R-R KÖKÜ TÜREVLERİ}

Gurūr kelimesiyle birlikte "ġrr" kökünün değişik formlarda ve aynı anlam çerçevesinde hadislerde de yer aldığı görülmektedir. Ebu Ca'fer'in rivayetinde Peygamber (s.a.v): "İman kalbe girdiğinde, kalp ona açlır, genişler." buyurdu, ardından: "Allah kimi hidayete erdirmek isterse göğsünü İslâm'a açar (el-En'âm/125)" ayetini okudu. Bu nasıl anlaşılır, belirtisi var mıdır yâ Resûlallah? sorusu üzerine: “ Evet vardır; ebediyet yurduna yönelmek ve gurūr (aldatma-kandırma) yurdundan uzaklaşmak ve ölümle buluşmadan önce ölüm için hazırlanmaktır." buyurdu. ${ }^{71}$ Ebu Ca'fer'in başka bir rivayetine göre $\mathrm{Hz}$. Peygamber: "Ebediyet yurdunu tasdîk eden birinin gurūr (aldatma-kandırma)

66 Mukâtil b. Süleyman, Tefsîru Mukâtil b. Süleymân, 1/325.

67 Taberî, Câmi'u'l-Beyân 'an Te'vîl-i 'Âyi'l-Kur'ân, 6/325.

68 Ferrâ, Yahyâ b. Ziyâd, Me 'âni'l-Kur 'ân (Beyrut: Âlemü'l-Kütüb, 1983), 1/251.

69 Zeccâc, Me 'ânî'l-Kur 'ân ve i 'râbuh, 1/500.

70 Mâverdî, en-Nüket ve'l-'Uyûn, 1/444.

71 İbn Ebî Şeybe, Ebu Bekr Abdullah b. Muhammed b. İbrahim, el-Mușannef, thk. Hamed b. Abdullah el-Cum'a - Muhammed b. İbrahim el-Lahyedân (Riyad: Mektebetu'r-rüşd, 1425/2004), 12/156. "Kitâbu'z-zühd" 8 (no: 35317); Hâkim, Ebû Abdillah Muhammed b. elHâkim en-Nisâbûrî, el-Müstedrek, thk. Mustafa Abdulkâdir Atâ (Beyrut: Dâru'l-kütübi'lilmiyye, 1422/2002), 4/346, “Kitâbu'r-rikâk k" 20 (7863). 
yurdu için koşuşturması ne şaşılacak bir durum!" buyurmuştur. ${ }^{72}$ Bu hadislerde yer alan gurūr kelimesinin, ayetlerde geçen gurūr kelimesiyle aynı mâna kapsamında kullanıldığı anlaşılmaktadır. Semüre b. Cündüb'ün rivayetine göre Hz. Peygamber imsak vaktiyle ilgili olarak: " Fecir iyice belli olmadıkça sakın Bilâl'ın ezanı ve şu ağartı sizleri aldatmasın." 73 derken, sakın sizleri aldatmasın ifadesini lā yeg்urrannekum olarak kullanmıştır. Ebu Hüreyre'nin rivayetine göre: "Namazda ve selamda noksanlık olmaz." ${ }^{44}$ buyurmuş ve noksanlığ g girār kelimesiyle ifade etmiştir. Câbir'in rivayet ettiği başka bir hadiste de: “Ümmetimin alınları (kıyamet gününde) abdestlerinden kalan izle ak olacaktır."75 buyurulmakta ve hadisteki $a k l \imath k$ gur kelimesiyle ifade edilmektedir. Gurūr kelimesi ve gar kökünden gelen kelimelerin, Kur'ân'da olduğu gibi hadislerde de aynı anlam çerçevesinde kullanıldığı görülmektedir.

Ulaşabildiğimiz kaynaklardan elde edilen örneklerle vuzûha kavuşturmaya çalıştığımız gurūr kelimesinin ve "grr" kökünden gelen diğer kelimelerin, Câhiliye döneminden İslam dönemine anlam kaybı veya kaymasına uğramadıkları, Kur'ân'ın inişiyle birlikte anlam derinliği kazandıkları anlaşılmaktadır. Kelimenin, Kur'ân-ı Kerîm ve hadislerde mâzi, muzâri, masdar ve mübâlağalı ism-i fâil gibi farklı formlarda geçtiğini görüyoruz.

\section{7. ĠURŪR KELIMESIINIIN TÜRKÇE'DE KULLANIMI}

Gurūr kelimesi, Türkçe'ye gurur şeklinde geçmiş olup konuşma ve yazı dilinde bu şekliyle kullanılmaktadır. Çalışmanın sonunda bu hususu ayrı bir başlık altında kısaca ele almanın uygun olacağını düşündük. Arapça'daki gurūr kelimesiyle yapı benzerliğini koruyan kelime Türkçe lügatlerde; boş ve beyhûde şeylere güvenip aldanma ${ }^{76}$, kurulma, mağrurluk ${ }^{77}$, kendini beğenme,

72 İbn Ebî Şeybe, el-Mușannef, 12/166. “Kitâbu'z-zühd” 8 (no: 35366).

73 Müslim, Ebû'l-Huseyn Müslim b. el-Haccâc, Ṣahih-u Müslim, hz. Muhammed Fuâd Abdulbâkî (Rıyad: Dâru's-selâm 1421/2000), “Kitâbu'ș-Ṣlyâm” 8 (no: 1094).

74 Ebû Dâvûd, Süleyman b. el-Eş'as b. İshak el-Ezdî es-Sicistânî, Sünenü Ebī Dâvûd, murâcaa: Sâlih b. Abdulazîz b. Muhammed b. İbrahim Âlu'ş-şeyh (Riyad: Dâru's-selâm li'n-neşr, 1420/1999), 171 (no: 928).

75 Taberânî, Ebû'l-Kâsım Süleyman b. Ahmed et-Taberânî, el-Mu'cemü'l-evsaț, thk. Tarık b. Avadullah b. Muhammed - Abdulmuhsin b. İbrahim el-Huseynî (Kahire: Dâru'lharemeyn, 1415/1995), 8/144 (No: 8222).

76 Sâmi, Şemseddin, “Gurur" Kâmûs-ı Türkî, Dersaâdet 1317/1899, Tıpkıbs. (İstanbul: Çağrı yayınlar11978), 965 . 
kibir, kurum, övünme, onur, şeref ${ }^{78}$ gibi manalarda açıklanmaktadır. Buradaki tanımlardan Arapça'daki gurūr kelimesinden mana izleri taşıdığı söylenebilirse de kelimenin, Türkçe konuşma ve yazı dilinde yerine göre kibir, daha çok da övünme, onur, şeref gibi manalarda kullanıldığı görülmektedir.

Burada belirtilmesinde yarar gördüğümüz bir husus şudur: Kelimenin günümüzdeki kullanımlarında görülen "gururum var" yerine, "şerefim, haysiyetim var", "gurur duyuyorum" yerine, "övünç duyuyorum" veya "iftihâr ediyorum" gibi ifade kalıplarının tercih edilmesi, kanaatimizce daha uygun düşecektir.

\section{SONUÇ}

Çalışmada öncelikle, Kur'ân'daki ġurūr kelimesi ve "grrr" kökünden gelen diğer kelimelerin Câhiliye dönemi Arap şiirinde de kullanıldığı ve Kur'ân'ın inişiyle birlikte bu kelimelerin anlam çerçevesinin genişlediği tespit edilmiştir. Bunlara ilaveten kök ve türevlerinin hadislerde nasıl kullanıldığına ve anlam farkı taşıyıp taşımadıklarına bakılmış, muhtelif formlarda kullanılan kelimelerin çalışmada belirlenen anlamları desteklediği görülmüştür. Lügat, tefsir ve terminoloji kaynaklarında yapılan birbirine yakın tanım ve açıklamalarda öne çıkan ortak mananın; kişinin bir takım zaafları yüzünden normal halin dışına çıkması sonucu maruz kaldığı aldanma, aldatılma olduğu, bunun da kelimenin kökündeki kırılma, kıvrım-büklüm anlamılla uyumlu düştüğü anlaşılmaktadır.

Kur'ân'ın farklı sûrelerindeki ayetlerde geçen kök ve türevlerinin genel ifadesiyle aldatma, aldanma anlamında kullanıldığı ancak, ayetlerin kendi bütünlüğü, bağlamı ve nüzul sebebine bağlı olarak aldatma ve aldanmanın sebep ve sonuçları itibariyle anlam incelikleri içerdiği görülmüştür. Ayetlere bakıldığında aldanma sebeplerinin başında, dünya hayatının câzibesi, mal-mülk, makam-mevki, boş hayâller-hevesler, şeytan iğvâsı gibi etkenlerin geldiğini, güdülen gaye ve hedefin de insana Allah'ı ve ahireti unutturmak olduğu anlaşılmaktadir.

77 Nâci, Muallim, “Gurur” Lü̆ğat-ı Nâci,nşr. Kirkor,y.y.,b.y, ts. Tıpkıbs. Çağrı Yayınları (İstanbul 1978) 549.

78 Eren, Hasan vd., “Gurur” Türkçe Sözlük, A-J, Yeni baskı (Anakara: Türk Dil Kurumu Yayınları, 1988.), 1/578. 
Gurur kelimesinin Türkçede de belli ifade kalıpları içinde kullanıldığı bilinmektedir. Çalışmada, Türk diline yerleşmiş olan bu kelimenin yapı benzerliğini koruduğu halde zamanla anlam değişikliğine uğrayarak övünme, onur, şeref, büyüklenme gibi manalar da kullanıldığına dikkat çekilmiş ve doğru kullanma şekillerine ışık tutulmaya çalışılmıştır.

\section{KAYNAKÇA}

Abdulbâkî, Muhammed Fuâd. el-Mu'cemu'l-müfehres li elfâà'l'-Kur'âni'l-Kerîm. Beyrut: Dâru ihyâi't-türâsi'l-Arabî, ts.

Abdurrezzâk b. Hemmâm es-San'ânî. Tefsîru'l-ḳurân.thk. Mustafa Muslim Muhammed. Riyad: Mektebetü'r-Rüşd, 1989.

Ahmed Muhtâr Omer. Mu'cemu'l-Lugaati'l-'Arabiyyeti'l-mu'âṣıra. Kahire: Âlemu'lkütüb, 1429/2008.

Âlûsî, Şehâbeddîn Mahmûd. Rûhu'l-Ma'ânî. Beyrut: Dâru İhyâi't-Türâsi'l-Arabî, ts.

Amr b. Ümmü Külsûm et-Tağlebî, Dîvân. thk. Eymen Meydan. Cidde: en-Nâdî'l-edebî es-sekâfî, 1992.

Askerî, Ebû Hilâl el-Askerî, el-Furûkư'l-Lugaviyye, thk. Muhammed İbrahîm Selîm, Kahire: Dâru'l-İlm ve's-Seḳâfe, 1997.

Beğavî, Ebû Muhammed el-Huseyn b. Mes'ûd el-Beğavî. Ma'âlimu't-Tenzîl. thk. Muhammed Abdullah en-Nemr-Osman Cum'a Dumeyriye-Süleyman Sâlim elHareş. Riyad: Dârutayyibe, 1412.

Beydâvî, Nâsıruddîn Ebu Said Abdullah b. Omer. Envâru't-Tenzîl ve Esrâru't-te'vîl.Thk. Muhammed Subhî Hasen Hallâk, MahmudAhmed el-Atraş. Beyrut: Dâru'r- reşîd Müessesetü'l-îmân, 2000.

Cevherî, İsmail b. Hammâd. es-Ș̣̂hâh. thk. Ahmed Abdulğafur Attâr. Beyrut: Dâru'lilmili'l-melâyîn, 1984.

Curcânî, Seyyid Şerîf el-Curcânî. Mu'cemu't-ta 'rîfâtt. thk. Muhammed Sddîk el-Minşâvî. Kahire: Dâru'l-fazîle, ts.

Ebû Dâvûd, Süleyman b. el-Eş'as b. İshak el-Ezdî es-Sicistânî. Sünenü Ebî Dâvûd. murâcaa: Sâlih b. Abdulazîz b. Muhammed b. İbrahi Âlu'ş-şeyh. Riyad: Dâru'sselâm li'n-neşr, 1420/1999.

Ebû Hayyân, Muhammed b. Yusuf el-Endelusî. el-Bahru'l-Muhị̂ț.thk. Âdil Ahmed Abdulmevcûd Ali Muhammed Muavvad. Beyrut: Dâru'1-Kütübi'l-ilmiyye, 1993.

Ebussuûd b. Muhammed el-İmâdî. İrṣâdu'l-'Akli's-Selîm ilā Mezâye'1-Kitâbi'l-Kerîm. thk. Abdulkâdir AhmedAtâ. Riyad: Mektebetu'r-Riyadı'l-hadîse, ts.

Eren, Hasan vd., “Sa'y” Türkçe Sözlük 2 K-Z. Anakara: Türk Dil KurumuYayınları, 1988. 
Ezherî, Muhammed b. Ahmed.Tehzîibu'l-Luga.thk. Abdusselâm Muhammed Hârun Muhammed Ali en-Neccar. Kahire: el-Müessesetü'l-Misriyyeti'l-âmme Ii't-te'lîf ve'l-enbâ' ve'n-Neşr-ed-Dâru'l-Misriyye Ii't-te'lîf ve't-terceme, 1964.

Ferrâ, Yahyâ b. Ziyâd. Me âni'l-Ḳur'ân.Beyrut: Âlemu'l-Kütüb, 1983.

Ferâhîdî, el-Halil b. Ahmed. Kitâbu'l-'Ayn. thk. Dr. Abdulhamid Hindâvî. Beyrut: Dâru'l-kütübü'l-ilmiyye,1424/2002.

Fîrûzâbâdî, Mecduddîn Muhammed b. Ya'kûb. el-Ḳâmûsu'l-Muhîț. thk. Mektebetu Tahkîki't-Türâs fî müesseseti'r-Risâle, Beyrut: Müessesetü'r-Risâle, 2005.

Fîrûzâbâdî, Beșâiru zevi't-temyîz fî lețâifi'l-Kitâbi'l-Azîz, thk. Abdul'alîm et-Tahâvî (Kahire: Lecnetu İhyâ'i't-türâsi'l-İslâmî, 1973).

Gazzâlî, Ebû Hâmid Muhammed b. Muhammed b. Muhammed el-Gazzâlî. İhyâu'ulûmi'd-dîn. Kahire: Mektebetu ve matbaatu Muhammed Ali Sabîh ve evlâduh. ts.

Hâkim, Ebû Abdillah Muhammed b. el-Hâkim en-Nisâbûrî. el-Müstedrek. thk. Mustafa Abdulkâdir Atâ. Beyrut: Dâru'l-kütübi'l-ilmiyye, 1422/2002.

Hasen el-Mustafavî, et-Taḥkîk fî Kelimâti'l-Ḳur'âni'l-Kerîm, Kahire - Londra: Merkezu Neşr Așar el-Allâme el-Mustafavî - Beyrut: Dâru'l-Kütübi'l-İlmiyye, 2009.

İbn Âşûr, Muhammed et-Tâhir. et-Taḥrîrve't-Tenvîr. Tunus: ed-Dâru't-Tûnisiyye li'nneşr, 1984.

İbn Atıyye, Ebû Muhammed Abdülhak b. Galib b. Atıyye el-Endülüsî. el-Muharrerü'1vecîz fī tefsîri'l-Kitâbi'l-'Azîz. thk. Abdüsselâm Abdüşşâfî Muhammed. Beyrut: Dârü'l- kütübi'l-ilmiyye, 2. Basım. 1422/2001.

İbn Ebî Hâtim, Tefsîru'l-Kur'âni'l-'Aẓ̂m. thk. Es'ad Muhammed et-Tayyib. Mekke\& Riyad: Mektebetu Nizâr Mustafa el-Bâz, 1997.

İbn Ebî Şeybe, Ebu Bekr Abdullah b. Muhammed b. İbrahim. el-Mușannef. thk. Hamed b. Abdullah el-Cum'a - Muhammed b. İbrahim el-Lahyedân. Riyad: Mektebetu'r rüşd, 1425/2004.

İbnu'l-Cevzî, Ebû'l-Ferec Cemaleddin Abdurrahman b. Ali b. Muhammed. Zâdu'l-Mesîr fî̀'Ilmi't- Tefsîr. Beyrut -Dımaşk: Mektebetu'l-İslāmī, 3. Basım. 1984.

İbn Dureyd, EbûBekr Muhammed b. el-Hasen b. Dureyd. Cemheretul'1-Luga. thk. Remzī Munîr Be'albekî. Beyrut: Dāru'l-ilmi Ii'l-melâyîn, 1987.

İbn Fâris, Ebu'l-HuseynAhmed b. Fâris, Mücmelü'l-Lugaa. thk. Zuheyr Abdulmuhsin Sultan. Beyrut: Müessesetü'r-risâle, 1986.

İbn Kesîr, İsmail b. Omer. Tefsîru'l-Kur'ânı'1-'Ažîm. thk. Sâmî b. Muhammed es-Selâme. Riyad: Dâru tayyibe, 1420/1999.

İbn Manzûr, Cemaleddin Muhammed b. Mükrrem. Lisânu'l-'Arab, thk. Abdullah Aliyyu'l-Kebîr - Muhammed Ahmed Hasbullah -Hâşim Muhammed eş-Şâzelî. 6 cilt. Kahire: Dâru'l-Me 'arif, ts. 
İbn Sîde, el-Muḥkemve'l-Muhîțu'l-A żam. thk. Abdulhamîd Hindâvî. 5 cilt. Beyrut: Dâru'l-Kütübi'l-ilmiyye, 2000.

İsfahânî, er-Râğıb el-İsfahânî. el-Müfredâtu fî garîbi'l-Ḳur'ân. thk. Muhammed Seyyid Keylânî. Beyrut: Dâru'l-ma'rife, ts.

Kurtubî, Ebû Abdillah Muhammed b. Ahmed b. Ebî Zekeriyyâ. el-Câmi’u li Aḥkâmi'lKur'ân. Thk. Abdullah b. Abdulmuhsin et-Türkî. 24 cilt. Beyrut: Müessetü'rrisâle,2006.

Mâturîdî, EbûMansûr Muhammed b. Muhammed el-Mâturîdî. Te'vîlâtu'l Kưr'ân. thk. Halil İbrahim Kaçar. İstanbul: Mizan Yayınevi, 2006.

Mâverdî, Ebû'lHasen Ali b. Muhammed b. Habîb el-Mâverdî. en-Nüket ve'l-'Uyûn.thk. Esseyyid b. Abdulmaksûd b. Abdurrahîm. 6 cilt. Beyrut: Dâru'l-kütübi'l-ilmiyye, ts.

Munâvî, Abdurraûf b. el-Munâvî. et-Tevḳ̂f'alâ muhimmâti't-teâ'rîf. thk. Abdulhamîd Sâlih Hamdân. Kahire: Âlemu'l-kütüb, 1410/1990.

Merkezü'd-dirâsât ve'l-ma'lûmâti'l-Kur'âniyye. el-Medhyal ilâ mevsûati't-tefsîri'l-me'sûr. 24 cilt. Beyrut: Dâr İbn Hazm, 1439/2017.

Muallim Nâci. “Sa'y”.Lüğat-ı Nâci. nşr. Kirkor. y.y.,b.y. ts. Tıpkıbs. İstanbul: ÇağrıYayınları, 1978.

Mücâhid b. Cebr. Tefsîru Mücâhid. thk. Muhammed Abdusselâm Ebu'n-Nîl. Kahire: Dâru'l-Fikri'l-İslâmîel-Hadîse, 1989.

Mukâtil b. Süleyman. Tefsîru Mukâtil b. Süleymān. thk. Abdullah Mahmud Şahâta. 5 cilt. Beyrut: Dâru't-târîhi'l-Arabî, 2. Basım. 1423/2002.

Müslim, Ebû́l-Huseyn Müslim b. el-Haccâc. Șaḥ̂ḥ̣-u Müslim. hz. Muhammed Fuâd Abdulbâkî. Riyad: Dâru's-selâm, 1421/2000.

Râzî, Muhammed er-Râzî Fahreddîn b. Allâme Ziyâeddîn Omer. Mefâtîhu'l-g̉ayb. 32 cilt. Beyrut-Lübnan: Dâru'l-fikr, 1401/1981.

Sâhib b. Abbâd. el-Muhîțfî́ll-Lugaa.thk. Muhammed Hasen Âl Yâsîn. 11 cilt. Beyrut:Âlemu'l-Kütüb, 1994.

Süfyân es-Sevrî. Tefsîru's-Sevrî. tsh. Ebu Ca'fer Muhammed. Beyrut: Dâru'l-Kütübi'lilmiyye, 1983.

Şemseddin Sâmi. "Sa'y" Kâmûs-1 Türkî. Dersaâdet. 1317/1899. Tıpkıbs. İstanbul:Çağrı Yayınları,1978.

Şinkîtî, Muhammedü'l-Emin, b. Muhammed. Eḍvâu'l-Beyân fî ị̂âhi'l-Ḳur'âni bi'l-Ḳur'ân. nşr. Vakfu müesseseti Süleyman b. Abdilazîz er-Râcihî el-hayriyye. 9 cilt. Cidde: Dâru âlemi'l-fevâid, ts.

Taberânî, Ebû'l-Kâsım Süleyman b. Ahmed et-Taberânî. el-Mu'cemü'l-evsaț. thk.Tarık b.Avadullah b. Muhammed - Abdulmuhsin b. İbrahim el-Huseynî.10 cilt. Kahire: Dâru'l-Haremeyn,1415/1995. 
Taberî, Ebû Ca'fer Muhammed b. Cerîr. Câmi'u'l-Beyân ‘an Te’vîl-i 'Âyi'l-Ḳur'ân. Thk. Abdullah Abdulmuhsin et-Türkî. 25 cilt. Kahire: Dâru Hecr, 2001.

Vâhidî, Ebû'l-Hasen Ali b. Ahmed b. Muhammed. et-Tefsîru'l-Basîț. thk. Nûra bint Abdulazîz el-Versân. 25 cilt. Riyad: Câmiatu İmam Muhammed b. Suûdelislâmiyye-İmâdetu'l-Bahsi'l-İlmî, 1430.

Zebîdî, Muhammed Murtadâ el-Huseynî. Tâcu'l-'Arûs. thk. Mahmûd Muhammed etTanâhî. 40 cilt. Kuveyt: Vezâretu'l-i'lâmfî'l-Kuveyt, 1993.

Zeccâc, Ebû İshak İbrahîm b. es-Seriyy. Me'âni'l-Kur'ân ve i râbuh. thk. Abdulcelîl Abduh Şelebî. 4 cilt. Beyrut: Âlemu'l-Kütüb,1988. 